\title{
Kirjandus tehnikaajastul ${ }^{1}$
}

Indrek Männiste, Jaak Tomberg

DOI: 10.7592/methis.v18i23.14797

\author{
mulle meeldib mõelda \\ (ja mida varem seda parem!) \\ kyberneetilisest aasast, \\ kus imetajad ja arvutid \\ elavad koos vastastikku \\ programmeeruvas harmoonias \\ nagu puhta vee \\ ja selge taeva kokkupuut. \\ (Brautigan 2007, 13)
}

Vähemalt 18. sajandi keskpaigast peale elame me tehnikaajastul. Tööstusrevolutsiooni esimene laine, mil inimtööjõult mindi järk-järgult üle masinatehnoloogiale ning käsitöölt tootmisele, markeerib nii moodsa majanduskorralduse kui ka meie silmanähtavalt tehnifitseeritud elu algust (vt Landes 1988, 1). Tuntud tehnikaajaloolane Lewis Mumford nendib et radikaalsed muudatused, mille säärane tehnoloogia abil inimkeskkonna ümberkujundamine endaga kaasa tõi, on „omakorda põhjustanud inimisiksuse teisenemise" (Mumford 2018, 13). Tõepoolest, tehnoloogilised leiutised on ümber seadistanud meie suhted iseendaga, ümbritsevaga ning tööriistade ja materjalidega, mida me kasutame (vt Goody 2011, 1; Kern 2003, 1). Praegu valitseb tehnika otsekui ajastu „terve mõistus“, kui ilmselge viis asjade tegemiseks (Borgmann 1987, 35). Tõsiasja, et me tehnika hiilivat kannakinnitust pole osanud tähele panna või karta, võib nähtavasti seletada nii asjaoluga, et seda on viimased paarsada aastat peamiselt samastatud üksnes vaadeldavate masina- ja seadmetehnoloogiatega, kui ka sellega, et tehnika kujutletud paljutõotavus on samaaegselt „nii tagant kihutanud kui ka pimestanud“ neid kolossaalselt ümberkujundavaid tegevusi, mis on meie ajastule andnud tema loomuse (samas). Üha enam tundub, et Heideggeril oli õigus, kui ta märkis, et tarve moodsa tehnika järele pärida „sureb välja samal määral, mil see tehnika maailmaterviku nähtusi ja inimese asetust selles otsustavamalt vermib ja juhib“" (Heidegger 1988, 1082).

1 Artikli valmimist on toetanud Eesti Teadusagentuuri grant .. Kirjanduslikud representatsioonid ja tehniline küllastumine: teadusliku fantastika realiseerumisest utoopilise realismini“ (PUT 1494). 
Tehnika ja tehnoloogia mõju on olnud kahtlemata määrava tähtsusega ka kultuuri- ja kirjandusloole. Ühel või teisel moel on kirjandus kõikidel ajastutel registreerinud inimese ja tehnika suhet. 20. sajandi lõpuks ei ole kirjandust võibolla isegi päriselt enam võimalik tehnikast iseseisvana käsitleda: sedavõrd kindlalt on ta istutatud tootmise, hävitamise, kopeerimise ja kommunikatsiooni tehnoloogilisse maailma (Goody 2011, 2). Kahtlemata on tehnoloogilistel muutustel on olnud laialdane mõju ka kirjandustekstide seesmistele vormidele: stiilile, retoorikale, kujundlikkusele, figuratsioonile, representatsioonile, süntaksile ja fraseerimisele (Danius 2006, 67).

Käesoleva artikli eesmärgiks on angloameerika kirjandustraditsiooni kaudu kaardistada olulisemaid kirjanduse ja tehnika kohtumisi läbi mõlema ideede-ajaloolise arenguloo. Säärasel keelelis-kultuurilisel kitsendusel on kaks peamist põh-

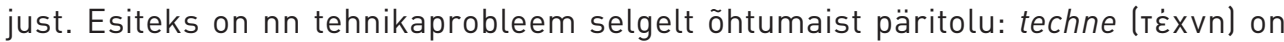
meie salgamatu filosoofiline pärand. Kuigi paljud tehnoloogiad eksisteerisid teistes kultuurides isegi varem, ei kaasnenud sellega sedavõrd ulatuslikku tehno-optimismi nagu lääne kultuuris. ${ }^{2}$ Veelgi enam, kuna tööstusrevolutsioon ja sellele järgnenud modernsus sündis Suurbritannias, on ehk isegi ainuõige käia tehnika käidud rada uuesti läbi selle keele ja kultuuri kaudu.

Meie peamine siht on ühelt poolt näidata, kuidas kirjandus on eri ajastuil võtnud taasesitada ühiskonnas toimuvaid tehnoloogilisi protsesse ning elanud oma valitud teemaliinide ja tegelaste kaudu läbi tehnika filosoofilist pöördeaega selle kõige üksikasjalisemates esinemis- ja tundmuskihtides. Teisalt, liikudes antiigist romantismi, realismist ja modernismist postmodernismi, näitame, kuidas tehnika, mida 18.-19. sajandi ilukirjanduses tajuti ja kujutati paljuski võõristavana, muutus 20. sajandil kõikehaaravaks tehnoloogiliseks küllastuseks: toimus üleminek „tehnoloogiliselt prosthesis'elt tehnoloogilisele aisthesis'ele“ ning tehnika, mida tajuti varem suuresti inimese suhtes välisena, liikus seetõttu inimeste siseilmadesse (Danius 2002, 3). Säärast tehnika ja tehnoloogia kogemise viiside muutust ja nende kirjanduslikke representatsioone on artikli ülesehituses püütud iseäranis rõhutada: kui romantismis ja realismis on võimalik kõnelda tehnikast üksikute võõristavate tehnoloogiliste motiivide kaudu (kaevandused, rongid jt), siis modernismis ja postmodernismis on elu ja aisthesis juba sedavõrd tehnikast kantud, et tehnika

\footnotetext{
2 Või nagu Mumford selle tabavalt on sõnastanud: „.. . . . kuigi neil [teistel kultuuridel] olid masinad, ei arendanud nad välja „Masinat“.” Mumford kirjutab: „See jäi selgelt lääne rahvaste asjaks - arendada füüsikalised teadused ja täppiskunstid välja määrani, mida ükski teine kultuur ei teinud, ning kohandada kogu oma elukorraldus masina rütmi ja kapatsiteedi järgi“ (vt Mumford 1934, 4).
} 
käsitlemine tehnoloogiliste üksikmotiivide kaudu ei suuda tehnika tegelikku mõjujõudu enam hõlmavalt esitada.

\section{Techne kui „päralelaskmine“ või „seadmine“}

Sõna tehnika algupäraks on vanakreeka techne (Tغ̇xvn). Techne omakorda pärineb indoeuroopa tüvest *tek, mis algselt tähistas „maja puust osiste kokkupanemist“ (Roochnik 1996, 19). Säärast spetsialisti, puutöölist või puuseppa hakati tähistama sõnaga tekton. Hiljem, nii Homerose, Sokratese kui ka Aristotelese juures, laienes techne mõiste juba peaaegu mistahes oskavale teadmisele või käsitööliste oskusele, olgu nendeks siis kingsepad, ravitsejad, kokad, kalamehed jpt (xiii). Techne teadaolev kirjanduslik traditsioon algab Homerose (8.-7. saj. ekr) kirjatöödega, kus techne'le on omistatud terve hulk tähendusi. Näiteks nimetab see sõna nii puuga töötava laevaehitaja „oskust“, Hephaistose „kunsti“, kes valmistab metallist lõksu sõjajumal Arese kinnihoidmiseks, Proteuse „kavalust“, kes on võimeline oma suva järgi kuju muutma, aga ka Aigisthose „plaani“ või „skeemi“ Agamemnoni mõrvamiseks (vt Roochnik 1996, 18). Seevastu Liddell, Scott ja Jones ${ }^{3}$ on välja toonud, et *tek ja *tekton omakorda viitavad algupärale *tikto, mis tähendab 'sünnitama' või 'esile kutsuma', mistõttu ka techne mõiste „on juba algselt teatud määral tootva tähendusvarjundiga“" (Roochnik 1996, 19).

Just see techne kõige algupärasem tõlgitsus võimaldas 20. sajandi nähtavasti kuulsaimal tehnikafilosoofil Martin Heideggeril (1889-1976) määratleda techne „ilmsikstoomisena“. „Sünnitamine“ või „,esilekutsumine“ tähendab Heideggeri tõlgitsuses esile-toomist: „veel mitteolemasoleval olemisse tulla“ laskmist (Heidegger 1989, 1200). Säärane techne käsitlus on otseselt seotud poiesis'e (noinoıc) mõistega, mis tähendab nii käsitöist valmistamist kui ka näiteks luuletamist või mõtlemist. Heidegger seob seesuguse tehnika esile-toomise aletheia mõistega ehk tõe või varjamatusega, kuna „esile-toomine sünnib ainult, kuivõrd varjatu tuleb varjamatusse“ (1201). Heideggeri meelest on see algupärane tehnika tähendus või olemus moodsal ajal radikaalselt teisenenud. Kuigi ka moodne tehnika on ilmsikstoomine, ei ole see enam poieetiline esile-toomine kreekalikus mõttes, vaid „väljakutse, mis seab loodusele püünise, hankimaks energiat“ (1203). Põhierinevus algupärase ja moodsa tehnika vahel seisneb peamiselt viisis, kuidas tehnikat vastava materjali või ressursiga ümberkäimiseks kasutatakse. Kui algupärases kreekalikus tähenduses kasutatakse tehnikat poieetiliselt esile-toomisena päralelaskmise tähenduses, siis

3 1843. aastal esmakordselt avaldatud vanakreeka-inglise sõnaraamat (.,Greek-English Lexicon“), mille esimesed koostajad olid Henry George Liddell ja Robert Scott, hiljem Henry Stuart Jones. See on vanakreeka keele leksikograafiline standardteos tänapäeval. 
moodne tehnika on Heideggeri meelest „väljanõudmine“: looduse või materjali „seadmine“ ehk käsitamine pelga ressursina või „koosseisuna“ inimese tarbeks. Eriomane suhe materjaliga, millest kreeka käsitööline või keskaegse gildi meister tõi oma käsitöökunstiga „ilmsiks“ või „varjamatusse“ vaagna või lusika, on Heideggeri meelest täiesti kadunud moodsa tehasetöölise käeliigutustes, kes „vajutab masinate kange ja nuppe“ (Heidegger 2004, 24). „Ei tööline ise, ei insenerid, veelgi vähem tehaseomanik [. . .] võib üldse teada seda, kus kaasaegne inimene ülepea „elab“ oma nii või teistsuguses suhtes masinaga või selle osadega“ (samas). Ning Heidegger lisab, et senikaua, ,kui me endi mõtteis tehnika olemusest siirameelselt ei hooli“, ei võigi me teada, mida industriaalsed masinad endast ülepea kujutavad, ega ka seda, mis asi see õigupoolest on, mille külge tehasetöölise käsi on kinnitatud (samas). Oluline on siin tähele panna, et moodsat tehnikat ei konstitueeri Heideggeri meelest pelk tööstusmasinate olemasolu ja pealetung: see osutub võimalikuks üksnes sel määral, kuivõrd moodsa tehnika olemus on juba saanud valitsevaks ja inimese enda „välja nõudnud“. „Meie ajastu“, kirjutab Heidegger, „ei ole tehniline selle tõttu, et see on masinaajastu; ta on masinaajastu sellepärast, et [ta] on tehniline ajastu“ (samas).

\section{Industrialism, romantism ja „sünged saatanlikud veskid“}

Tehnika „väljanõudmise“ või „,seadmise“ tähenduses saab meile arusaadavamaks tööstusrevolutsiooni ning sellega seotud mastaapsete muutuste kontekstis. Kui oma algses kreekalikus tähenduses oli tehnika seotud kogu inimloomusega ning osa suuremast kultuuritervikust ja igas mõttes „elukeskne“, mitte pelgalt tööega võimukeskne (Mumford 2018, 24), siis tööstusrevolutsioonist peale näeme s e a d va tehnikaajastu ennastkehtestevat iseseisvumist. Suurbritannias sündinud tööstusrevolutsioon märgitses läänemaailmas sajandeid domineerinud majanduselu katkestust ja suunamuutust. Kuni 18. sajandi alguseni oli Suurbritannias, nagu mujalgi Euroopas, tooni andnud toetumine põllumajanduslikule elu- ja majanduskorraldusele, mida toetas lihtne käsitööndus ning lokaalne kaubandus ja kaubavahetus (Wyatt III 2008, 40). 1750-1850 muutus Suurbritannia järk-järgult agraarühiskonnast moodsaks, industriaalseks ja linnastunud ühiskonnaks ning 1850. aastaks sai sellest maailma rikkaim riik. Selle hiiglasliku transformatsiooni peamisteks põhjusteks oli aurumasina leiutamine ja hüppeline areng tekstiilitööstuses Inn „pöörleva Jenny“ leiutamine), kivisöe kaevandamises ning rauatööstuses. Aurumasina leiutamist James Watti poolt 1784 peetakse osaliselt ka tänapäevase kliimakriisi esmaseks tekkepõhjuseks, kuna kivisöe põletamisel põhinevast tööstustest tekkinud süsinik(dioksiid) hakkas ladestuma laialdaselt üle maailma (Morton 2013, 4). Aurumasinat võib pidada ka tinglikult moodsa arvuti eellaseks selle universaalse 
kasutusala ja võimaluste tõttu: seda oli võimalik ühendada rohkearvuliste masinate assamblaažidega ja sedasi varustada neid ajamjõuga. Säärast keerulistel aurumasinasüsteemidel põhinevat industrialismi on nimetatud „kummastavaks küberneetiliseks süsteemiks“ või ka omamoodi „primitiivseks tehisintellekti liigiks“ (5). Kivisöe- ja auruenergia käivitasid järjest keerulisemaid masinaid ning võimaldasid loobuda inimese-, looma-, tuule- ja vee-energiast, millele oldi toetunud sajandeid. Muuhulgas kujundas söekaevandamine ümber ruraalse Kesk-Inglismaa ja kattis suitsu ja tahmaga nii ümbritsevad majad kui ka inimeste kopsud (Tiles 2009, 237).

Industrialiseerimise ning urbaniseerimise hüppeline tõus, mil traditsioonilised töövõtted ning inimsuhted hakkasid hääbuma, pani paljusid kirjanduse- ja kultuuriinimesi umbusaldama ajastu mõistuse- ja teaduseusku filosoofe ja filosoofiaid (Punter 1991, 107). Romantistlik kirjanduslik reaktsioon (1780-1830) industrialismi suhtes hakkas ennast sageli väljendama suitsevate korstnate, mürarohkete vabrikute ja idülliliste maastikukirjelduste vastandamise kaudu. Alguses prantsuse valgustusliikumise ideaalidele kaasa elades muutus romantism hiljem kriitiliseks selle põhiideede suhtes, nagu mõistus, teadmine ja teadus (Ferber 2010, 64), mille „dialektiline“ programm jutlustas küll vabadust, ent mille tagajärjeks oli Theodor Adorno ja Max Horkheimeri arvates tegelikult orjastamine: tehnoloogia muutmine instrumendiks, mille abil anastada loodust ning ekspluateerida inimesi lvt Adorno ja Horkheimer, 1947).

Inglise tuntuimad romantistlikud luuletajad, William Blake ja William Wordsworth, võtsid oma loomingus selge hoiaku ajastu sotsiaalsete, kultuuriliste, poliitiliste ja ajalooliste muutuste vastu. Oma luulekogumikes „Süütuse ja kogemuse laulud“ (.,Songs of Innocence and of Experience“, 1789; 1794) kritiseerib Blake ajastu korrumpeerivat linnaelu, kuhu vaesem osa põllumajandusega tegelevatest inimestest oli sunnitud ümber asuma ning vabrikutes elatist otsima. Lüüriliselt lihtsad, ent siirad luuletused nagu „Korstnapühkija“ (1789; 1794) ja „London“ (1794) juhivad kriitiliselt tähelepanu vaesusele, sotsiaalsele ebavõrdsusele, laste ekspluateerimisele tööjõuna ja linnaelu ängistavale loomulaadile ning moraalsele allakäigule industriaalses olemiskorras (vt Blake 2004a, 5-6; 2004b, 11). Blake'i tuntud värsirida „sünged saatanlikud veskid“ (1808) interpreteeritakse sageli varajase tööstusrevolutsiooni kriitikana, milleks ta ammutas inspiratsiooni esimese Londoni päristehase, aurujõul töötava Albion Millsi jahuveski 1791. aastal põlengus hävinud varemetest.

William Wordsworthi poeetilised igatsused inimese ja looduse kooskõla järele kasvasid välja sarnastest muredest. Selgitades „Lüüriliste ballaadide“ I..Lyrical Ballads“, 1798) eessõnas oma „programmi“, rõhutab Wordsworth, et tarvitades tavaelu juhtumite ja olukordade kirjeldamiseks „,seda keelt, mida inimesed päriselt 
kasutavad“, ent andes neile samas teatava „kujutlusvärvingu“, loodab ta neis tõeselt tabada „looduse algseadusi“ (Wordsworth 2004, 86). Wordsworth kutsub inimesi truuks jääma „Looduse kaunitele ja püsivatele vormidele“ (samas) ning tema mõte on, et kui me üritame nende vormidega suhelda, elame me eriomase intensiivsusega. Ent industrialism ja tehnoloogia takistavad meil nende vormidega suhtlemist ning seetõttu vaesestavad meie elu. Ta pidas luulekeelt väljenduse eriliseks vahendiks, mis võib aidata vaimul ja loodusel kujuteldavalt taas üheks saada. Jonathan Bate on säärast romantismi enesevisiooni nimetanud ökopoeetikaks (Bate 2000, 245).

Wordsworthi poeetiline kutse loodusesse pöördus iroonilisel kombel isegi ta enda vastu, kuna tema „Järvede teejuht“ (.,Guide to the Lakes“), mis müüs rohkem kui ükski tema luuleraamat, tõi hiljem tema kodukanti Järvemaale (Lake District) rongitäite viisi esteetilise piktoreski januseid keskklassi päevareisijaid ning tema sulneist maastikest ning maakodust said „viktoriaanlikud turismiatraktsioonid“ (vt Bate 2002, 128; Väljataga 2004, 24). Poeedi kirjeldatud loodus oli nüüd ajastule omaselt s e a t u d turismitööstuselt ja käsitatud pelga k o o s s e i su na .

Proosakirjandusest leiame hoiatuse tehnika ja teaduse liiga sinisilmse progressimeelsuse aadressil Mary Shelley romaanist „Frankenstein“ (1818). Romaan näitab meile esoteerilise loodusteadlase Victor Frankensteini elu ja töö näitel, kuidas sügavast kirest sündinud, ent järelemõtlemata teaduseksperimendil võivad olla traagilised tagajärjed nii looja kui ka loodu jaoks. Algsest saavutuse- ja kuulsuseihast pimestatuna õpib Frankenstein valusate isiklike kogemuste kaudu, kui ohtlik võib olla „,arutu uudishimu“ (Shelley 2007, 142) ja „,lubamatu leiutamine“ (61), ja mida õigupoolest tähendab teadlase vastutus oma tehtu tagajärgede eest (113). Romaani kurvaks lõpuks jõuab Frankenstein arusaamisele, et teadlase mistahes üllatest või isiklikest eesmärkidest on tähtsaim kohustus „kaasinimeste“ ja nende „õnne ja heaolu“ ees (147).

Tehaste ja kaevanduste õõva tekitavad motiivid ilmuvad laiemalt proosakirjandusse alles 1840. aastatel. Elizabeth Gaskelli „Mary Barton“ (1848) ja „Põhi ja lõuna“ (.,North and South“, 1854) on žanrilises mõttes võibolla esimesed „,tõelised“ industriaalromaanid. Tõeliselt romantistliku „süüdistuskokkuvõtte“ industrialismist ning selle ideoloogiatest leiame Charles Dickensi romaanist „Rasked ajad“ (.,Hard Times“, 1854) (vt Ferber 2010, 252). Romaan põhineb Dickensi isiklikul kogemusel tema enda toimetatud ajakirja Household Words tarbeks kogutud reporterilugudel tööstusrevolutsiooni kohta ning mitmed romaanitegelaste prototüübid pärinevad Prestoni tekstiilitööliste streigi (1853-1854) vahetust kogemusest. Kuigi Dickens oli nii oma ajakirjalugudes kui ka romaanides industriaalühiskonna suhtes äärmiselt kriitiline, ei pidanud ta ennast reformijaks, vaid pigem satiiriliseks moralistiks, kes 
osutab vastloodud industriaalühiskonna ilmselgetele kitsaskohtadele (Schor 2001, 64). Romaan kirjeldab elu fiktiivses tööstuslinnas Coketownis (Koksilinnas), mis sümboliseerib tüüpilist tolleaegset Põhja-Inglismaa tööstuslinna. Dickens pilab nn utilitaristlikku filosoofiat, mille järgi inimesed peaksid elama üksnes faktidele ja teaduslikule teadmisele, aga mitte fantaasiale tuginedes. Grotesksete tegelaste kaudu, nagu tööstur Bounderby ja kooliõpetaja Gradgrind lendine pensionile jäänud rauatarvete hulgikaupmees), maalib Dickens meile sünge pildi ühiskonna ja inimvaimu mehhaniseerimisest tööstushulluse ajastul.

\section{Rongid, sensatsionalism ja realism}

19. sajandi keskpaigaks oli suur osa põhilisi industriaaltehnoloogiad muutunud tavapäraseks igapäevaelu osaks. Tootmine intensiivistus veelgi ning reisi- ja kommunikatsioonitehnoloogiad muutusid järjest kiiremaks ning meelelahutusele ja puhkusele pühendatud aeg ja selle kvaliteet tõusis märgatavalt (Goody 2011, 4). Üheks tehnoloogiaharuks, mis ühiskonna teadvust sellel ajajärgul nii põhistas kui ka pelutas, oli 1830. aastatel avatud ja järjest laienev kommertsiaalne rongiliiklus. Kuid rongiliiklus ei olnud pelgalt uudne transpordiliik, vaid see kehastas nii toimija kui ka sümbolina argielu järsku kiirendust: see hävitas eksisteerinud aja- ja ruumikogemuse ning esitas reisija tundemeelele uusi nõudmisi. Varasem kaarikust või hobuse seljast nähtuv aeglaselt lahtirulluv maastikuvaade transformeerus möödatormavaks maailmaks, mis näis paigalseisva reisija suhtes liikuvat. Kuna inimese silm polnud harjunud nägema vilksamisi mööda sööstvaid objekte, pidi ta alles õppima kauguses olevat panoraami fokusseerima (Nye 1994, 53). Koos kaasaegse linna ja tehaseolustikuga tarvitses ka raudtee ja rongiliiklus niisiis inimestelt uut tüüpi subjektiivset suunatust (Daly 1999, 463). Ärevus industrialismi ja masinakultuuri suhtes, mis iseloomustas 1840.-1850. aastate kirjandust, jäi püsima veel väga pikaks ajaks. See ärevus leidis märkimisväärse väljenduse näiteks 1860. aastate melodramaatilistes rongiõnnetuse-lavastustes, mis olid ülipopulaarsed nii viktoriaanlikul Inglismaal kui ka Ameerikas. Kasutades rikkalikke valgustusefekte, tossu ja kõikvõimalikke illusioone, etendasid sellised lavastused nagu „Peale pimedat: üks jutustus Londoni elust“ (.,After Dark: A Tale of London Life“, 1868), „Gaasilambi all“ (.,Under The Gaslight“, 1867-1868) ja „Insener“ (.,The Engineer“, 1863) ikka ja jälle samal motiivil põhinevat lugu: raudteeliiprite külge seotud tegelase, kelle suunas sõidab täiskiirusel rong, päästab viimasel hetkel peakangelane või kangelanna. Masinate ohtlikkust ja hirmu, mida need tekitavad, kasutatakse neis näidendeis ära selliselt, et tehnoloogiline ähvardus pigem „šokeerib kui traumeerib“ publikut. Närvekõditav stseen pakub ühelt poolt võimaluse fantaseerida industriaalsuse eest põgenemisest, ent ühtlasi ja paradoksaalselt tirib nii peategelase kui 
ka publiku tegelikult veelgi sügavamale selle temporaalsusesse: kollektiivselt tajutavasse ajastumeelsusesse (Daly 2004, 2; 32).

Rongid ja raudtee esinevad mingi uue reaalsuse esindajatena olulisel moel ka Mandri-Euroopa realistlikus/naturalistlikus kirjanduses. Näiteks Lev Tolstoi eepilises romaanis „Anna Karenina“ (1878) on rong ja raudtee mitmetahuline tähenduse edastaja, mis pole keskne ainult romaani ülesehituslikust küljest, vaid esindab tervet võrgustikku, mis ühendab romaani temaatilisi liine. Ühelt poolt on raudteemotiiv tervet romaani struktureeriv element: Anna ilmub esmakordselt lugeja ette ja ka lahkub temast raudteejaamas. Samuti saab ronge ja raudteed lugeda siin vene kõrgklassi ning selle elulaadi ja moraali esindajana ning Anna enesetappu kui sellele alla vandumist või sellele vastu seismist: Anna otsustab anda järele endas peituvatele individuaalsetele, spontaansetele ning loomulikele jõududele, mis lömastatakse rongi/ühiskonna poolt (Jahn 1981, 3).

Émile Zola, kes oli naturalistliku kirjandusžanri üks peaideolooge, uskus, et kirjandust tuleb teha nagu teadust: inimese kui objekti uurimine tuleb ka kirjanduses allutada objektiivsetele ja determineeritud teaduslikele põhimõtetele ja meetoditele (vt Cambpell 1997). Loodusteaduste usku ajastult innustust saades sõnastas Zola „eksperimentaalse romaani“ idee, mis seadis endale eesmärgiks

[. . .] vallata teadmist nendest mehhanismidest, mis inimeses olemas on; näidata inimese vaimsete ja tundmuslike väljenduste masinavärki, mida mõjutavad nii pärilikkus kui ka keskkond, just nii nagu füsioloogia meile seda näitab; ning lõppeks välja pakkuda inimest selliselt, kuidas ta nondes samades ühiskondlikes tingimustes elab, mis ta ise endale loonud on [. . .]. (Zola 1893, 20-21)

Zola ühes „,kirjanduslikus eksperimendis“, romaanis „Inimelajas“ I.,La Bête Humaine“, 1890) on rong ja raudtee romaani täielikult konstitueerivad elemendid. Tegelastega asetleidvaid sündmusi, nende asukohti ja teemaliine juhivad minutilise täpsusega väljuvad ja saabuvad rongid ning kümned raudteejaamade nimed. Enamik romaani tegelasi on kas otseselt või lähedaste kaudu seotud raudteel töötamisega. Romaani ühel peategelasel, mõrvamõtetest vaevatud vedurijuhil Jacques Lantier'l, on intensiivne ja isikustatud „suhe“ oma veduri Lisoniga. Lantier „nühib ja poleerib“ alatasa oma veduri osi (Zola 2013, 123) ja tunneb „,ainult oma veduril end rahuliku, õnneliku ja maailmast sõltumatuna“ ning armastab seda, kuna „masin oli nagu õnne pakkuv, rahustav armuke“ (47). Lantier usub, et erinevalt teistest samalaadsetest mass-toodetud veduritest on tema Lisonil „hing“, kuna selle „valmistamises kätkev saladus, see miski, mille metallile lisab valutöö ja iga üksikosa monteeriva töölise käsi“ on kinkinud tema masinale „kordumatu isiksuse elu“ (122) ning kehastab Lantier'le „metallolendite ülimat ilu, täpsust ja jõudu“ (121). Nagu näeme, 
usub Lantier, et algupärane techne mõiste meistri hooliva ja isikliku suhtena töödeldavasse materjali ja loodavasse esemesse pole kõrgindustrialismis veel päriselt kadunud ning võib harvadel juhtudel väljendada isegi veel poiesis'liku päralelaskmise tähenduses. Lantier omistab vedur Lisonile sageli kas naise või hobuse omadusi ning romaani VII peatükk toob lugeja ette kaasahaarava loo veduri ja looduse võitlusest lumevangi sattunud raudteel, mille vapper vedur lõppeks siiski kaotab. Veduri raskusi kirjeldav kaasatundev poeetiline keel sarnastab masina „setukaga“ (154), kes kord „rühib tublilt ja sujuvalt“ (152) siis „omatahtsi galopeerib“ (152) ja „korskab ja sülitab“ (153) ning lõppeks „raskelt hingeldades“ (156) enam paigalt ei liigu. Hiljem vedur „sureb“ armukadeda Flore’i poolt mahitatud kokkupõrkes kiviplokkidega täidetud vankri pahatahtliku raudteele sättimise tõttu ning tema surmaagooniat kirjeldatakse jällegi kui armastatud hobuse „surmakorinat“ (238-239).

\section{Modernism, teadvusevoog ja durée}

Sajandivahetusel jätkunud kiired ning radikaalsed muutused tehnoloogia arengus tekitasid jätkuvalt kahetisi tundeid ajastu kultuuriteadvuses: ühelt poolt tunti nende saavutuste üle „meeletut uhkust“, kuna oldi võimelised kontrollima oma elukeskkonda sedavõrd ulatuslikul määral, ent samal ajal tunti ka ärevust selle üle, et tehnoloogia „muudab lõplikult inimeseks olemise sisu“ (Wilson 2009, 40).

Üheks silmapaistvamaks tehnika eestkõnelejaks oli futuristide liikumine eesotsas Filippo Tommaso Marinettiga, kelle 1909. aastal ilmunud manifest sõnastas futurismi kiirendatud moderniseerimise liikumisena, mis kätkes endas joovastavat optimismi tehnoloogia, linnaelu ning itaalia rahvusliku mõtte uuendamise suhtes (Miller 2006, 169). Futuristid vaimustusid tehnika poolt võimaldatavast kiirusest, militarismist ja patriotismist ning nende ideid on seostatud Mussolini hilisemate fašistlikke visioonidega Itaalias. ${ }^{4}$

Futuristidest mõjutatuna kirjutas teinegi kirjanduslik tehnikaapologeet, Ezra Pound, 1920. aastatel: „.. . . . ] nii nagu me ei saa Achilleuse kilpi välja jätta „Iliasest“, ei saa me ka masinaid välja jätta modernsest teadvusest.“ Poundi vaimustasid „tavalised masinad“ ning nende osad: silindrid, kolvid, mutrid, poldid jms. Oma essees „Masinakunst“ (.,The Machine Art“, 1927-1930) uuris Pound mustvalgelt lakoonilisel, varuosade kataloogilikul viisil ülespildistatud masinate detaile, mis ilmnesid talle esteetiliselt rahuldustpakkuvate objektidena. Teda huvitas masinate „formaalne ilu“, nende nii plastilised kui ka kõlalised omadused. Pound leidis, et tehnoloogilise objekti ilu oli olemuslikult kätketud selle eesmärki ja funktsiooni. Ta

\footnotetext{
4 Põhjalikumat käsitlust futurismi kohta vt Tiit Hennoste käesoleva ajakirjanumbri artiklist ..Johannes Semper hobusega. Avangard, takerduja tehnika ja looduse vahel“.
} 
mõistis suurepäraselt, et paljud inimesed on tüdinud masinapõhisest „progressist“ ning et enamasti seostavad inimesed masinaid „,inetuse ja põrgulärmiga“ (Pound $1996,59)$. Soovides säärast perspektiivi muuta, uskus Pound, et masinaesteetikast võib mõelda täiesti iseseisvalt üksnes ilu enese kategooriates (Danius 2006, 66).

Paljud 1920. aastatel ilmunud, modernismi klassikaks kerkinud romaanid, nagu Andrei Belõi „Peterburg“ (1922), James Joyce’i „Ulysses“ (1922), Thomas Manni „Võlumägi“ (.,Der Zauberberg“, 1924), Virginia Woolfi „Proua Dalloway“ (.,Mrs. Dalloway“, 1925), Marcel Prousti „Kadunud aega otsimas“ (.,À la recherche du temps perdu“, 1913-1927) jpt moodustasid omamoodi moodsa tehnika intensiivistumise ja tavaellu kinnistumise kirjeldamise kroonikad.

Prousti „Kadunud aega otsimas“, mis on muljetavaldav monument subjektiivsele temporaalsusele, personaalselt kogetud ajale, orkestreerib tervet hulka tehnoloogilisi leiutisi (automobiilid, telefonid, lennukid jms). See on ka üks viise, kuidas Proust ehitab üles kadunud aegade temaatika. Sarnaselt mitmete enda kaasaegsetega uurib ka Proust seda, .,kuidas uued masinad ja nende keskkonnad muudavad maailmas olemise viise“ (Danius 2006, 67). Võib öelda, et Proustilt leiame me võibolla isegi ühe varaseima ja nüansirikkaima mõtiskluse selle kohta, kuidas kuulmise ja nägemise kinnistunud viisid mehhaanilise taastootmise ajastul muutuvad (samas).

Thomas Manni entsüklopeedilist romaani „Võlumägi“ (1924) iseloomustab rõhk pilgule ja visuaalsele kogemusele. Romaani peategelane Hans Castorp puutub sanatooriumis viibides esmakordselt kokku terve rea tema jaoks uute tehnoloogiatega: röntgeniaparaadi, kinofilmi, grammofoni ja paljude teistega. Kõiki neid kohtumisi võib pidada teatavaiks verstapostideks peategelase haridus- ja arenguteel. Iseäranis oluline on lugeda Manni romaani tollal vasttärkavate visuaaltehnoloogiate kontekstis, mis „avasid uusi optilisi ruume“ ja seetõttu ka uusi teadmise valdkondi (Danius 2002, 57). Romaani peamist tegevuspaika, sanatooriumi iseloomustatakse paljuski visuaalsete tegevuste kaudu. Vaadatakse teisi inimesi, maale, fotosid, röntgeniplaate, maastikku, läbi mitmesuguste optiliste „ajaviiteesemete“ nagu näiteks „stereoskoopiline vaatekast“, ., pikksilmakujuline kaleidoskoop“ ja .,keerlev trummel“ (Mann 2008, 116). Romaani iseloomustavateks visuaalseteks markeriteks on just seetõttu peetud „sotsiaalset skaneerimist, meditsiinilist pilku ja mehhaanilist silma“ (Danius 2002, 61).

Modernistlik kirjandus ei käi tehnoloogiliste muutustega ümber pelgalt temaatiliselt. Nagu Prousti töödes, laseb see ennast märgata ka mitmete teiste 20. sajandi alguse kirjanike tekstide seesmise vormi tasanditel: stiili, retoorika, kujundlikkuse, figuratsiooni, representatsiooni, süntaksi ja fraseerimise juures.

Modernistlik romaan võttis väljendada ühiskonnas toimuvaid muutusi kirjanduslikus vormis, mis ise samaaegselt muutus. Modernism näitas, et maailma „pidi 
vaatama igast vaatenurgast, isegi kui fikseeritavaid vaatenurki ei ole“ (Orr 1991, 619). Üheks modernistlikku kirjanduse eriomasemaks stilistiliseks iseloomujooneks võib kindlasti pidada nn teadvusevoo (stream of consciousness) narratiivset laadi. Psühholoog William Jamesilt nime saanud jutustamismeetod kirjeldab sündmusi tegelaste mõtetevoogudena, mis on sageli kirja pandud ilma kirjavahemärkideta ja mittelineaarses ajalises järjestuses. „Selles pole midagi ühendatud; ta voolab [. . .]", kirjeldas James selle stiili eripära. Teadvusevoo stiili kõige kuulsaimaks näiteks on kahtlemata James Joyce’i „Ulysses“ (1922). Kasutades Homerose „Odüsseiat" omamoodi toetava vundamendina, kujundab Joyce tuntud eepose ümber Dublini tavainimeste (Stephen Dedalus, Leopold Bloom ja Molly Bloom) ambivalentsete uskumuste ja modernismi-eetose vastukäivate väärtuste kirjeldamiseks ühe päeva jooksul (16. juuni 1904). Joyce kasutab kõige tavalisemaid inimesi selleks, et näidata lugejale ühelt poolt 20. sajandi alguse Dublini linnaelu tavakogemise erinevust ja mitmeplaanilisust, aga teisalt ka sarnasusi, mida ühise linnaruumi kodanikena jagatakse. Igapäevaelu monotoonse argisuse täpne kirjeldamine ja tavaliste inimeste mänguline vastandamine Homerose eepilistele kangelastele moodustab ühtekokku omamoodi modernse eepose: üks kõige tavalisem päev, „mil kõige tavalisemad inimesed teevad kõige tavalisemaid asju“ muutub ühtäkki erakordseks lvt Bogost 2016). Teadvusevoo stiili (või ka sisemonoloogi) eesmärk on tegelaste mõttemustrite esiletoomine „ilma tavapäraste üleminekuteta, mida tarvitatakse konventsionaalsetes narratiivides“ (Gillespie 2006, 388). Säärane stiil mitte üksnes ei näita lugejale, mida tegelased mõtlevad, vaid pakub ka võimaluse näha, mil moel tegelased moodustavad oma muljeid. Üks stiilinäide Leopold Bloomi mõtisklustest:

Härra Bloom kõndis mõõdetud sammul piki Söör John Roggersoni kaldapealset [. . .] Brady barakkide juures lösutas üks prükkaripoiss, tapajäätmete ämber käevangus, ja suitsetas äranäritud konijuppi. [. . . U Ütleks poisile, et ta ei kasva, kui suitsetab. Oh, Las ta olla! Ega temagi elu just lust ja lillepidu ole. Ootab kõrtsiuste ees, et iss koju viia. Tule koju emme juurde, iss. Vaiksevõitu kellaaeg: ega seal palju rahvast ole. (Joyce 2017, 2207-2208)

„Ulyssese“ stiilide paljusust, milles on lahti öeldud fikseeritud seisukohast, on peetud „mitmekordseks esiletoomiseks“ või paljastamiseks (Orr 1991, 620). See tähendab, et stiilide paljusus ei kätke endas lihtsalt fikseeritud teema suhtelisi variatsioone, s.o eri vaatenurki fikseeritud objekti vaatlemiseks, vaid need on „stiilimuutused sobitamaks muutuvaid objekte muutuva maailmaga“ (samas). Nõnda saab ühest päevast Dublinis põhjatu kuristik. Reaalsus ei ole enam selgepiiriliste osatäitjate lõikuvate perspektiivide rakendamine maailmale, sest maailm ise ei ole enam „konsensuslik nägemisväli“ (samas). Modernismikogemuses ei või me eales 
kindlad olla, et tervik on osade summa, ega ka selles, et meie taju kogetavat ammendab.

Joyce”i „Ulyssese“ ja Prousti teoste kõrval on teadvusevoo väljapaistvamaks meistriks kindlasti ka Virgina Woolf. Romaanis „Proua Dalloway“ kasutab Woolf peategelast Clarissa Dallowayd uuenenud kultuurilise mõju avaldumis- ja kogemisväljana: olgu selleks linnaruumis kogetavad uued tehnoloogiad nagu automobiilid, lennukid ja kino, või siis ka Clarissa moodne avatus abielu- ja seksuaalsuhetele ning ühiskonnas toimuvatele poliitilistele protsessidele. Teadvusevoo meetod, mida Woolf tarvitas, väljendas „vajadust liikuda väljapoole faktuaalse realismi kohmakusest ning leida tundlikumaid, kunstilisemaid ning sügavamõttelisemaid viise“ selleks, et tabada moodsa ühiskonna muutunud loomulaadi (Showalter 2016). Öeldes lahti lineaarsest jutustamislaadist ning soovides rõhutada käeolevat hetke esmatähtsust - aga nii, et minevik selles edasi elaks, mõjutas Woolfi otseselt nii Albert Einsteini relatiivsusteooria kui ka Henri Bergson, kelle filosoofiline ajamõiste durée - muutis kardinaalselt käibivat lineaarset ajakäsitlust. Durée on mineviku pidev edasikulgemine, mis murrab ennast välja tulevikku ning areneb ning paisub seal veel edasigi. Minevik kasvab Bergsoni sõnul ilma, et see lakkaks olemast, ning tema püsimajäämisele pole mingeid piiranguid. Näeme, kuidas „Proua Dalloways“, mille sündmused toimuvad samuti ühel juunikuupäeval Londonis, „elavad“ peategelased üheaegselt nii minevikus kui ka olevikus. Clarissa jutustav sisemonoloog põimub eksplitsiitsete Londoni sündmuste virvarris läbi tormiliste neiuea mälestustega maakodus Bourtonis, ning teine peategelane, Septimus Smith, elab Londoni tänavatel kõndides ikka ja jälle läbi oma traumaatilist sõjakogemust. Mõlema personaalset teadvusevoogu lõikavad läbi linnaruumis kogetavad tehnoloogilised katkestused nagu kohtumine arvatava võimukandjat sõidutava autoga, taevasse reklaami tippiva lennukiga, aga ka sündmusi alatasa saatvate Big Beni kellalöökidega (Sims 2001, 120). ${ }^{5}$

John Dos Passose „suur Ameerika triloogia“ „U.S.A.“ (1938), mis koosneb romaanidest „42. laiuskraad“ (.,The 42nd Parallel“), „1919“ ja „Suur raha“ (.,The Big Money“), on mitmetahulise modernismikogemuse kirjanduslikku vormi valamise katse stiilinäide. Dos Passos kasutab triloogias nelja alatasa vahelduvat narratiivset häält. Romaani fiktsionaalse narratiivi moodustavad kaheteistkümne tegelase elukirjeldused oma koha otsinguist 20. sajandi alguse Ameerika ühiskonnas. Iga tegelane on esitatud omamoodi bildungsroman'ilikul viisil, tegelaste elu- ja arengu-

5 Põhjalikumat analüüsi tehnikast Virginia Woolfi loomingus vt Indrek Männiste käesoleva ajakirjanumbri artiklist ..Kirjandus, kontrapunkt ja cantus technicus“. 
kaart vaadeldakse varajasest lapsepõlvest täiskasvanuks kujunemiseni. Teise narratiivse tasandi moodustavad „Kaamerasilma“ (.,Camera Eye“) osad, mis on kirjutatud teadvusevoo stiilis ning mida peetakse Dos Passose enda autobiograafiliseks „kunstnikuromaaniks“, mis järgib tema kujunemist lapsepõlvest poliitiliseks kirjanikuks, aga kommenteerib autori perspektiivist ka romaanis asetleidvaid avalikke sündmusi. Just seda osa on peetud romaanis kõige „avangardlikumaks“ IGilman 1997). Kolmanda narratiivse hääle moodustavad nn „Ringvaate“ (.Newsreel“) osad, mis koosnevad ajalehepealkirjadest, artiklite fragmentidest, populaarsete laulude sõnadest, päevauudistest jms ning kannavad romaanis edasi autentset ajastuhõngu. Romaani viimase narratiivse alaosa moodustavad Ameerika tuntud ajalooliste tegelaste minibiograafiad. Siit leiame teiste hulgas näiteks Henry Fordi, Woodrow Wilsoni, Isadora Duncani ja Thomas Edisoni elulood. Dos Passose sedavõrd mitmekülgse stilistilise valiku üheks eesmärgiks on peetud Ameerika kultuuri „,vastindustriaalse ja kommertsiaalse visuaalsuse “ kriitilise taasesitamine püüdu (North 2004, 141). Eisensteini filmidest ja D. W. Griffithi montaažitehnikatest kaasa haaratuna mõjub Dos Passose „U.S.A.“ filmiliku kollaažina, mis püüab hoiatavas kõverpeeglis jäädvustada Ameerika elulaadi ja ideaalide kokkuvarisemist tegelaste luhtunud elude näitel: lennundusentusiastist Hollywoodi näitlejani ning poliitilisest spin doctor' ist suurtöösturi ja madruseni.

\section{Tegelikkuse tehniline küllastumine}

Kui mitte varem, siis II maailmasõjas Natsi-Saksamaa teostatud genotsiid ning Ameerika Ühendriikide heidetud tuumapommid Hiroshimale ja Nagasakile märkisid sümboolset äratundmishetke, et inimestevaheliste võimusuhete realiseerimine võib nihkuda täienisti tehnilisele pinnasele ning inimeksistents kui niisugune võib sattuda inimeste toodetud tehnika ja tehnoloogiliste süsteemide täielikku meelevalda. USA juhtiva holokausti-ajaloolase Christopher Browningi sõnul eristab holokausti teistest genotsiididest kaks asjaolu: esiteks „kavatsuse totaalsus ja ulatus“ ning teiseks eesmärgi täitmiseks kasutatud vahendid - „modernse rahvusriigi ja lääne teadusliku kultuuri administratiiv-bürokraatliku ja tehnoloogilise suutlikkuse rakendamine“ (Browning 2000, 32). Goody lisab, et holokausti tootmisliinilik tapatöö, mida Hannah Arendt on kutsunud ka „Laipade masstootmiseks“ (Arendt 1973, 441), põhines „absoluutse objektiivsusega juhitud masinavärgi tõhususel“ (Goody 2011, 85). Tuumarelv kujutab endast seevastu ,tehnoloogia surmava jõu apoteoosi“ (78) - esimest korda inimajaloos tunnetati sedavõrd sügavalt, et totaalset kollektiivset hävingut ei pruugi põhjustada enam üksnes „inimvälised“, nt looduslikud või jumalikud jõud, vaid tehnika, mille inimene on ise välja töötanud. Goody ütleb, et erinevalt igapäevaselt kasutatavast tehnoloogiast kogeti tuumarelvi sõjajärgsetel 
aastakümnetel „sümboolsete või kujutluslike artefaktidena“ (samas). Tohutu kultuuriline mõju, mille tuumaenergia ja -relvad heitsid varjuna üle kogu 20. sajandi teise poole, ei põhine mitte selle tehnoloogia tagajärgede vahetul kogemisel, vaid „alalisel ohul kogu elule ja kogu tsivilisatsioonile, ebakindlusel inimkonna tuleviku suhtes, mille on põhjustanud tema enese loodud tehnoloogia“ (samas). Pettumine tehnoloogilises progressis, mille põhjustas holokaust, ning inimkonna saatuse sattumine tema enese kätesse, mida märkisid tuumarelvad, rajasid teed postmodernistlikku kirjandust nii sisuliselt kui ka vormiliselt kujundavale „suurele“ juhtmotiivile: usaldamatusele suurte narratiivide vastu (vt Lyotard 1997, xxiv). Nii võib öelda, et tehnikal oli kogu 20. sajandi teise poole kirjandusele ja kirjanduslikule kujutlusvõimele subtiilne, kuid kõikemäärav mõju.

Teadusliku ja statistilise maailmapildi süvenemine, bürokraatiaaparaatide laienemine, masstootmise hüppeline tõhustumine ning sellega kaasnenud tarbimisühiskonna teke, salvestus-, paljundus- ja infoedastustehnoloogiate kasvaval efektiivsusel põhinev massikultuuri teke ning peaaegu iga eluvaldkonda läbistav üha kiirenev tehn(oloog)iline innovatsioon viis II maailmasõja järgsetel aastakümnetel läänelike ühiskondade kultuuritegelikkuse tehnilise küllastumiseni. Sellist küllastumist ilmestab hästi prantsuse filosoofi Jacques Elluli tuntud uurimus „Tehnoloogiline ühiskond“ (1953), milles Ellul vaatleb inimese ja masina/tehnoloogia vahelise suhte muutumist kultuuris, kus tehnika on saavutamas üha suuremat autonoomsusastet. Elluli käsitluse aluseks on tehnika ning masina/tehnoloogia otsustav eristus:

Termin tehnika ei tähenda minu kasutuses masinaid, tehnoloogiat või mõne eesmärgi saavutamiseks mõeldud protseduure. Meie tehnoloogilises ühiskonnas on tehnika nende ratsionaalselt saavutatud meetodite totaalsus, millega (antud arengufaasis) on igas inimtegevuse vallas jõutud absoluutse tõhususeni. [. . .] Tehnika pole ühiskonnas isoleeritud asjaolu (nagu termin tehnoloogia võiks meid uskuma panna), vaid see on seotud moodsa inimese elu iga valdkonnaga; see mõjutab nii sotsiaalseid kui ka kõiki muid asjaolusid. (Ellul 1964, xxv)

Tehnika ja masin/tehnoloogia pole niisiis Elluli jaoks identsed, ehkki „masin on sügavalt sümptomaatiline: see representeerib ideaali, mille poole tehnika püüdleb. Masin on ainumalt, eksklusiivselt tehnika; võiks öelda, et see on puhas tehnika“ (4). Tehnika ja tehnoloogia niisugusest eristusest lähtuvalt täheldab Ellul nende omavahelise (representatsioonilise) suhte järk-järgulist muutumist:

Senikaua kui tehnikat representeeris ainuüksi masin, oli võimalik rääkida „inimesest ja masinast“. Masin jäi välispidiseks objektiks ning inimene jäi sellest hoolimata iseseisvaks. Ta võis kehtestada end masinast eraldiseisvalt; ta oli suuteline sellega suhestuma. Kuid kui tehnika 
siseneb elu privaatsfääri, kaasa arvatud inimesse, lakkab see olemast inimese suhtes väljaspoolne ning saab tema tõeliseks substantsiks. See ei seisa enam inimesega vastakuti, vaid on temasse integreeritud ning haarab ta järk-järgult endasse. Selles mõttes erineb tehnika radikaalselt masinast. See transformatsioon, mis moodsas ühiskonnas on nii silmanähtav, tuleneb asjaolust, et tehnika on muutunud autonoomseks. (Ellul 1964, 6)

Teisisõnu, tehnika polnud 20. sajandi teisel poolel enam midagi ainiti „välispidist“, mille suhtes inimene saanuks asuda selgelt piiritletud, „turvalisele“ või kontrollivale distantsile. Pigem oli kogu (kultuuriline) tegelikkus ise muutunud läbinisti tehniliseks - ning inimene tehnikaseadestu isetoimimise suhtes omakorda üha teisejärgulisemaks ja sekkumisvõimetumaks. Tehnika sellist „iseseisvumist“ on looduse ja tehnika muutunud suhte raamistuses täiendavalt iseloomustanud USA kirjandusteadlane Istvan Csicsery-Ronay. Tema käsituses pole tehnoloogia enam kaugeltki miski, mida inimesed üksnes kasutavad selleks, et oma igapäevaelu paremaks muuta. Selle asemel on tehnoloogiat „, hakatud pidama omaette ajalooliseks jõuks“ (Csicsery-Ronay 2008, 93) ${ }^{6}$ ning tegelikkus, mida see jõud vormib, koosneb „kompleksse[test] ja vaevu hallatava[test] protsessid[est]“ [CsicseryRonay 2008, 26). Tehnoloogia pole enam üksnes „üksiku leidurist või avastajast veidriku“ privileeg, vaid hõlmab „kogu liiki“ (Csicsery-Ronay 2008, 93). See enam „mitte üksnes ei imiteeri loodust“, vaid „transformeerib tegelikult materiaalset maailma, kasutades teaduslikku teadmist moel, mil see paneb oma füüsilise substraadi toimima nii, nagu Loodus „ei toimi““.” (samas). Tehnoloogiast on sestap saanud autonoomne teine loodus, mis „sirutab [. . .] end välja mateeria tuumani“ (samas). Nendes mõtetes heliseb kaasa Fredric Jamesoni tuntud määratlus postmodernismist kui ajastust, kus „moderniseerumisprotsess on lõpule viidud“ (Jameson 1999, ix), ning postmodernistlikust kultuurist kui usutavalt toimivast „,teisest loodusest“ (samas). Tehnoloogia - ning sedakaudu ka tehnika kui niisugune - on postmodernsel ajastul miski, mida tajutakse ühtaegu nii intiimselt lähedalseisva kui ka isetoimivalt autonoomse ja kõikemääravana.

\section{Tehnika postmodernistlikus kirjanduses}

20. sajandi teise poole angloameerika kirjandusest võib välja tuua ridamisi tekste, kus tehnoloogia on eksplitsiitselt ning tehnika implitsiitselt teose temaatilise ja vormilise mõjujõu keskmes. George Orwelli tuntud düstoopia „1984“ (1949,

6 See on mõnevõrra sarnane Martin Heideggeri lähenemisega, mis pidas tehnikat „ajastu metafüüsikaks“ ning rõhutas, et moodne tehnika „ei tulene inimese otsusest, vaid hoopis protsessidest olemise ajaloos endas“ (vt Zimmerman 1990, xiii). 
eesti k 1990) hoiatas kirjutamise kaasajas kujunema hakanud külma sõja raamistuses totalitarismi uute vormide eest, mille toimimise tagavad esmajoones üha tõhusamad jälgimistehnoloogiad. Thomas Pynchoni II maailmasõda käsitleva postmodernistliku suurromaani „Raskusjõu vikerkaar“ (.,Gravity’s Rainbow“, 1973; eesti k 2017) süžeelises ja sümboolses fookuses on sõdivate vastaspoolte püüdlused saavutada kontroll uusima sõjatehnika üle ning kitsamalt sakslaste V2-raketid, mis juhtuvad Londonis kukkuma kohtadele, kus peategelane Tyrone Slothrop on sattunud sugulisse vahekorda astuma. J. G. Ballardi skandaalne romaan „Crash“ (1973, eesti k 2013) käsitleb täienisti autostunud suurlinna ning jutustab loo Londoni äärelinna magistraalidel tegutsevast subkultuurist, mille liikmete igapäeva täidab autoõnnetuste intensiivne fetišeerimine, kuulsuste autokokkupõrgete üksikasjalikkuseni hoolikas lavastamine, õnnetuspaikade innukas fotografeerimine, õnnetussündmuste teaduslik lahkamine, proteeside ja haavaarmide tähelepanelik ja andunud uurimine, lakkamatu haiglapalatites taastumine, üha järgmiste laupkokkupõrgete või õnnetussimulatsioonide põhjalik ja toimekas planeerimine, neist tuleneva seksuaalse iha rahuldamine jne. Don DeLillo kõrgelt auhinnatud romaanis „Valge müra“ (.,White Noise“, 1985, eesti k 2005) hakkab ühe USA Kesk-Lääne väikekodanliku perekonna perepea surelikkust ja surmahirmu raamistama rongiõnnetuse tulemusel keskkonda lekkinud keemiareostus. William Gibsoni küberpunk-romaanis „Neuromant“ (.,Neuromancer“, 1984; eesti k 1997) palgatakse häkker Case abistama võimsat tehisintellekti, et too saaks küberruumis ühilduda oma kaksikuga ning moodustada üliteadvuse, mis hakkab kontrollima Matrixi-nimelist globaalset virtuaalvõrgustikku.

Niisugust loetelu 20. sajandi teise poole kirjandusteostest, mille temaatilist või esteetilist paleust kujundab mõni kirjutamise kaasajas uus tehn(oloog)iline motiiv ja selle kriitilised järelmid, võiks jätkata veel pikalt. Uued tehnoloogiad tekitavad tänase päevani vaimustusel või võõritusel, entusiasmil või võimetustundel põhinevat tunnetuslikku peapööritust, mis leiab oma kajastuse kirjanduses. Kuid tehnoloogiline innovatsioon, selle kiirus ja intensiivsus - asjaolu et uusi tehnoloogilisi nähtuseid tuleb pidevalt peale - on ise muutunud kultuuriliselt enesestmõistetavaks. See on miski, mida ollakse harjunud olevikult ja tulevikult eeldama. Sestap on ka mõistetav, et postmodernistlikus kirjanduses ei tõuse üks või teine tehn(oloog)iline motiiv esteetilise mõjujõu allikana enam sedavõrd jõuliselt esile, nagu nägime romantismi, realismi või modernismi juures. Kultuur ei vastandu enam nii selgepiiriliselt loodusele, tehnika ei seisa enam orgaanilise inimkeha suhtes selgelt määratletaval distantsil: kogu kultuuriline eksistents ühes inimkehadega, mis sellesse on haaratud, on nüüd läbinisti tehnika poolt seatud. Tehnika, nagu ütleb Ellul, pole enam inimese suhtes väljaspoolne, vaid on saanud tema tõeliseks substantsiks. 
Sestap pole ka 20. sajandi teise poole ja uue sajandi alguse (postmodernistlikust) kirjanduse juures mõtet kõneleda mitte niivõrd üksikutest tehnloloog)ilistest motiividest, mida see representeerib, vaid kogu kultuuritegelikkuse ning tervete suurte eluvaldkondade (tarbimisühiskond, massimeedia, massikultuur, kultuuritööstus, bürokraatiaaparaat jne) substantsiaalsest tehnilisusest, mida esitab ja kehastab ka kirjandus.

Nii osutab Orwelli „1984“ jälgimistehnoloogia motiivi kaudu kriitilises võtmes asjaolule, et tehnika oma konkreetses kasutuses pole iseeneses midagi neutraalset, vaid mängib suurte ideoloogiliste formatsioonide ülesehituses ja alahoius fundamentaalset rolli. V2-rakett Pynchoni maksimalistlikus „Raskusjõu vikerkaares“ pole pelgalt isoleeritud tehnoloogiline motiiv, vaid võti „mitmemaailm[sesse] ruum[i], kus ekslevad tegelased, kes esindavad erinevaid maailmavaatelisi, keelelisi ja erialaseid registreid ning kes hõlmatakse tohutusse kultuuriliste, sõjaliste, ajalooliste jne seoste võrgustikku“ (Kraavi 2018). Autot ja autoõnnetuste fetišeerimist võib Ballardi „Crashis“ lugeda sõnasõnaliselt, kuid õigupoolest tagab see kujundina representatsioonilise ligipääsu määrale, mil tehnika on moodsas ühiskonnas inimkehasse tunginud, tekitades sedakaudu paradoksaalsel kombel nii afekti kui ka identiteedikadu, nii tõmbe- kui ka tõukejõudu. DeLillo „Valge müras“ käivitab peategelase eksistentsiaalse sisekaemuse keemiareostus kui täienisti tehn(oloog)ilist päritolu sündmus, mille mõju ei suuda summutada ega kinni katta ka andumine kõikvõimalikele (taaskord täienisti tehnilise loomusega) tarbimisühiskondlikele rutiinidele, mille roll moodsa identiteedi kujundamisel on romaani tegelikuks tuumstseeniks. Küberruumi Gibsoni „Neuromandis“ ei tuleks tõlgendada üksnes ühe toonase tulevikulise võimalikkusena, vaid metafoorse kujustusena, mis aitab paremini tajuda täienisti tehnilise hiliskapitalistliku maailmasüsteemi pealtnäha hoomamatut paljusust - selgitustöö, mida Fredric Jamesoni arvates teevad kõige paremini just tehn(oloog)ilised figuurid (Jameson 1999, 34-38). Nii saaks peaaegu iga postmodernistliku teose puhul näidata, kuidas see tehnika toimet ja mõju avab ja mõtestab: kõigile neile on võimalik vaadata kultuuritegelikkuse tehnilise küllastumise perspektiivist. Kirjandus tehnilise küllastumuse ajastul on selle küllastumusega alati paratamatus suhtes.

\section{(Postmodernistlik) kirjandus tegelikkuse tehnilise küllastumuse ajastul}

Kuid olulisemaks eri viisidest, kuidas postmodernistlik kirjandus on tehnikat representeerinud ja mõtestanud, tuleks pidada tehnilise küllastumise mõju kirjanduse enese narratiivsele kokkuseadele, poeetikale, vormile, loomemeetoditele ja üldisele mõtestusele. Paljud postmodernse kultuuri ja postmodernistliku kirjanduse paleust määratlevad tuntud juhtmõtted on hõbeniiti pidi tagasi viidavad just 
kultuuritegelikkuse tehnilise küllastumuse lätetele. Jõuame neile osutada üksnes põgusate pintslitõmmetega. Nägime juba, kuidas II maailmasõja traumaatilised raputused ning nendega kaasnenud inimkonna tehnilise häviltalmise võimalikkuse läbitunnetamine viis süveneva pettumuseni tehnoloogilises progressis ja kasvava ebakindluseni inimkonna tuleviku suhtes. Need kujundasid uue ajastu kultuuritunnetuslikuks põhifooniks, aga ka omamoodi eetiliseks imperatiiviks usaldamatuse suurte narratiivide suhtes, mida tänini peetakse üheks postmodernse kultuuri ja kirjanduse juhtmotiiviks. Hoidumine „modernistliku teadmise mudelite“ (Lyotard 1997, xxiii) asetamisest ainuselgitavasse positsiooni, keeldumine müütiliste mõõtmetega lugude (nt kristluse ja lunastusõpetuse, saksa klassikalise spekulatiivse filosoofia, marksismi ja sotsialismi, kapitalismi jne; vt Kraavi 2005, 76) ainuautoriteedist tähendas kirjanduses ühtlasi universaalsuse asemel erinevuste ja heterogeensuse produtseerimist (79).

Sestap ei anna maksimalistlik romaan kui postmodernistliku kirjanduse kõige massiivsem ja monoliitsem „suurvorm“ edasi mõnd (vertikaalset) suurt narratiivi, vaid püüab (horisontaalselt) esitada, koondada ja kokku võtta postmodernse kultuuritegelikkuse peaaegu hoomamatut paljusust ja mitmekesisust, väikelugude võrgustikku, millest see koosneb. ${ }^{7}$ Sellisele erinevuste ja heterogeensuse produtseerimisele vastas omakorda autoriteetse ja kehtestava autori- ja jutustajapositsiooni nõrgenemine ning kirjaniku kontseptsiooni ümbermõtestamine, mida iseloomustab kõige paremini veel üks postmodernistlik juhtmõte, Roland Barthes'i tuntud idee autori surmast.

Me teame nüüd, et tekst ei koosne sõnadereast, mis kannaks endas ühtset, mingis mõttes teoloogilist tähendust (Autor-Jumala „sõnumit“), vaid ta on mitmemõõtmeline ruum, kus omavahel põimuvad ja põrkuvad erinevad kirjutused, millest ükski pole algupärane: tekst on tuhandetest kultuurikolletest pärinevate tsitaatide kude. (Barthes 2002, 122)

Seda heterogeenset tsitaatide kude toodab kirjaniku asemel pigem kirjutaja, keda Barthes on iseloomustanud otseselt tehnilistes terminites: „Kirjanik sarnaneb preestriga, kirjutaja ametnikuga“ (14). Kui kirjanik on klassikalises vaimus individuaalne kunstnik-geenius, kes edastab „Autor-Jumala“ sõnumit, siis kirjutaja kujutab endast täienisti tehnilist funktsiooni, mis toodab ja haldab omavahel põimuvaid ja põrkuvaid kirjutusi. Sellest vaatenurgast kõlab tabavalt Janek Kraavi sedastus, et lahtiütlemine „individuaalse kunstnik-geeniuse rollist“ tõi endaga kaasa „postmo-

7 Põhjalikku ülevaadet maksimalistliku romaani kohta vt Ercolino 2014. 
dernistliku kirjaniku loomingukeskkonna [. . .] teistsugused tekstilised strateegiad“, mis võrsuvad selle keskkonna tehnilise küllastumuse pinnalt: „varjamatu tsiteerimine, paroodilisus, irooniline mäng massikultuuri vormidega, kõrge ja madala kultuuri süntees“" (Kraavi 2005, 170).

Ühtse ja autoriteetse autoripositsiooni õõnestumine avaldub 20. sajandi teise poole kirjanduses väga erinevate kirjutamismeetodite kaudu. Rakendatakse ebausaldusväärset jutustajat, „vaatepunktide paljunemist, mitmete jutustajate olemasolu, mitmesuguste tuntud kirjavormide kaasamist teksti (nt politseiraporti vorm või keel), mingi ajaloolise stiili imiteerimist, stilistika (või maski) taha peitumist jne " (174). Kõigi nende meetodite märgatav vabakasutus märgib ühtlasi kirjutaja-instantsi enese fundamentaalselt tehnilist loomust, tema (teadvustatult) tehnilist suutlikkust hallata ja manipuleerida saadavalolevaid kirjanduslikke kirjutusviise ja -võimalusi. Nii on ka metafiktsionaalsuses - veel ühes postmodernistlikus juhtstrateegias midagi põhiolemuselt tehnilist. Seades saladust tegemata kahtluse alla tekstis konstrueeritava reaalsuse idee, esitades seda varjamatult kui väljamõeldist, rõhutades „fiktsionaalse reaalsuse keelelist olemust ning objektiivse maailmakirjelduse võimatust, indiviidi mõtlemise sõltuvust keelest ja diskursustest“ (175), kehastab iseäranis just metafiktsioon kirjutaja teaduslik-tehnilist teadlikkust kirjutuse staatusest ja kirjutamise mehhanismidest. Narratiivi sekkuv jutustaja, lugeja lülitamine loominguprotsessi, stilistiline ja vormiline hübriidsus ja mitmekesisus, dokumentalism, „realismi“ efekt, tüpograafilised mängud, raamatu kujundusliku külje toonitamine, sihilik intertekstuaalsus (vt samas) - kõik need annavad omamoodi tunnistust tõsiasjast, et postmodernistlik kirjutaja opereerib kirjandusliku „toorainesega“ samamoodi nagu tehnika opereerib tehnilise küllastumuse ajastul loodusega.

Mõistagi on selge, et ülaltoodud tekstistrateegiliste tunnuste mõjulepääs postmodernistlikus kirjanduses pole lihtsalt ja sirgjooneliselt taandatav üksnes kultuuritunnetuslikule usaldamatusele suurte narratiivide vastu, milleks andis aluse inimkonna tehn(oloog)ilise hävimise perspektiiv. Tehniline küllastumine läbistas sõjajärgsete aastakümnete lääneliku kultuuri kõiki eluvaldkondi ning mõjutas sedakaudu ka kirjanduse s(t)aatust. Massikultuuri teke ja globaalne levik hägustas ja tühistas „kõrgete“ ja „madalate“ kultuuriregistrite vahelisi piire ning intensiivistas nendevahelisi mõjusõlmi. Kultuuritööstuse otsustav mõjulepääs tarbimiskultuuris määras ära uued kirjastamis- ja turundusstrateegiad, kujundas ümber kirjanduse žanrisüsteemi ning tõstis prominentsele kohale näiteks kõikvõimaliku žanrikirjanduse. Kultuuriruumi kasvav vaatemängulisus (vt Debord 2013) ning sellega kaasnenud tegelikkuse simulatsiooniline kvaliteet (vt Baudrillard 1999) teisendas arusaama reaalse ja virtuaalse, tegelikkuse ja väljamõeldise vahekorrast ning sedakaudu ka kirjandusliku fiktsioonimaailma staatusest. Teadusliku ja tehnloloog)ilise arengu kiirus ja 
intensiivsus kujundas ümber kultuurilise aegruumitaju, nõrgendas suutlikkust mõtestada olevikku ajalooliselt ning lõimida tähenduslikult ühte minevikku, olevikku ja tulevikku (Jameson 1997). See tõi omakorda kaasa (vabastavad) vabamängud varasema kultuuri märkide, jutustamislaadide ja stilistikaga ning viis traditsioonilise ajaloolise romaani väljenduslaadi dekonstruktsioonini ja ajalookirjutuse olemuse kriitikani (vt Kraavi 2005, 173). Kõikide nende aspektide kaudu on võimalik näidata, kuidas tehnika areng mängis 20. sajandi teise poole kirjanduse paleuse kujundamisel määravat rolli. Kirjandus tehnilise küllastumuse ajastul on vähemalt samavõrra selle küllastumuse sümptom kui selle küllastumuse mõtestaja ja kriitik.

Eelmise sajandi viimasel aastakümnel läänelikku argielu ümber kujundama hakanud digitaalsed ja võrgustikulised kommunikatsioonitehnoloogiad avaldasid uut laadi mõju ka kirjanduse konventsionaalsete vormide tajumisele ning rajasid teed uutele loojutustamis- ja esitlusvõimalustele. Hüpertekst (vt Landow 2006), Jorge Luis Borgese „Hargnevate teede aia“ omamoodi digitaalne kujustus, võimaldas jutustada mitmesuunalisi lugusid ja realiseerida korraga paljusid loolisi võimalikkusi, vabastas narratiivi veelgi enam sirgjoonelise lineaarsuse kammitsaist ning suurendas otsustavalt lugeja osalust lugemisjärjestuse ja loo kulgemise määramisel. Digitaalne esitusviis võimaldas konventsionaalselt staatilise kirjanduskirja liikuma panna ning lõimida kirjanduskogemusse uudsel ja märksa strukturaalsemal viisil pilte, heli ja filmikatkeid. Tekst taandus digitaalses kirjanduses üheks paljudest teose komponentidest, muutis kirjandusteose rõhutatult intermediaalseks. Internetikeskkond lõi klassikaliste kirjastamismehhanismide kõrvale uut laadi kirjanduskultuuri, kus ei kehtinud enam „aktiivse“ autori ja „passiivse“ lugeja dihhotoomia - igaüks võis oma loomingu potentsiaalselt väga paljudele kiiresti kättesaadavaks teha või varem avaldatud lugusid omast entusiasmist edasi ja kaasa luua Inn fännikirjandus). Selle kõrval ähvardas digitaalse kirjastamise ja e-raamatute esiletõus käesoleva sajandi esimesel kümnendil esialgu konventsionaalse materiaalse raamatuvormi autoriteeti õõnestada, kuid need hirmud osutusid alusetuks - digitaalse ajakirjanduse, reklaamitööstuse ning sotsiaalmeedia ajastul kujutab materiaalne raamat oma puhta ja askeetliku kirjavormiga hoopis omamoodi vastumürki või pagemisteed üha audiovisuaalsema ja infomürarikkama igapäeva eest. ${ }^{8}$

\footnotetext{
8 Kanoonilist käsitlust digitaalse kirjanduse kohta vt Hayles 2008; head eestikeelset ülevaadet digitaalse kirjanduse defineerimise ja periodiseerimise kohta vt Viires 2017 ning Marin Laagi ja Piret Viirese artiklist käesolevas väljaandes.
} 


\section{Teadusulme kui tehnikakirjandus}

Viimaks tuleb öelda, et käesolev käsitlus kirjandusest tehnikaajastul poleks piisav, kui sellest jääks välja osutus ulmekirjandusele - ning iseäranis teadusulmele (science fiction), mis eraldi žanrina on teaduslik-tehnilise maailmapildi kõige ilmselgem ja sirgjoonelisem kirjanduslik manifestatsioon. Teadusulme on laiaulatuslik kirjandus-, kunsti- filmi-, muusika- ja meediažanr, mis Andrus Oru sõnul „kujutab kunstiliselt usutavas laadis teaduse ja tehnika mõju inimesele ja ühiskonnale ning tehnokultuurilise arenguga seotud muutuste võimalikkust“" OOrg 2017, 140). Teadusulme on tehnikakirjandus par excellence, see kui ajaloolis-kultuuriliselt kujunenud žanr ,huvitub paljude teadusvaldkondade uurimissuundadest lsh küberneetikast, kvantmehhaanikast, kosmoloogiast, info-, geeni-, nano- ja femtotehnoloogiast), nendega seotud probleemidest, hüpoteesidest ja perspektiividest, ennekõike aga tehnoloogilise tulevikuühiskonna ettekujutuslikust modelleerimisest teaduslike teadmiste taustal“ (samas). Teadusulmeteos seondub peaaegu alati eksplitsiitselt selle kirjutamise kaasaja teaduslike ja tehn(oloog)iliste arenduste viimase sõnaga, aidates sedakaudu mõtestada parasjagu prevaleerivaid ühiskondlikke ideoloogiaid, sotsiaalpoliitilist konteksti, tehnokultuurilist arengut ja sellega seonduvaid eetilis-humanistlikke küsimusi (144-145). Teadusulme keskne struktuurielement, noovum, mis Darko Suvini määratluse kohaselt on „kõikehaarav innovaatiline nähtus või suhe, mis erineb autori ja eeldatava lugejareaalsusnormist “ (Suvin 1979, 64), on peaaegu alati teaduslik-tehnilist laadi. Eri viise ja vorme, kuidas teadusulme on tehnikat representeerinud, inimese ja tehnoloogia suhet mõtestanud ning kirjutamisaja tehnoloogilist hetkeseisu tulevikku ekstrapoleerinud, võikski siin jääda üles loetlema - alates inimkonna teaduslike innovatsioonipüüdluste mitmesugustest kirjeldustest kuni kriitiliste käsitlusteni tehnika otsustavast mõjust tehnikaajastu inimese aegruumitajule ning tehnika otsustavast sissetungist inimkehasse ja -psüühikasse. Käesoleva arutluse seisukohast on oluline märkida, et äratundmist kultuuritegelikkuse tehnilise küllastumuse kohta kehastab ka teadusulme teisenev positsioon nüüdisaegses žanrisüsteemis - asjaolu, et teadusulme on uuel sajandil hakanud võtma üha realismilähedasemaid vorme (vt Tomberg 2013), ning tõsiasi, et väga paljud tunnustatud , peavoolu“ autorid (Margaret Atwood, David Mitchell, Jonathan Lethem jnel kasutavad oma nüüdisaegsete kriitiliste ambitsioonide teostamiseks üha enam just nimelt teadusulmelisi temaatilisi motiive ja poeetilist tööriistakasti.

Kirjandus reageerib muutuvatele kultuurioludele alati väikese lõtkuga - sestap on suure tõenäosusega veel ilmumata teosed, mis kajastavad hõlmavalt näiteks sotsiaalmeediast ja klikiajakirjandusest läbiimbunud kultuuritegelikkust ning selle toel võrsunud populistliku avaliku ruumi praeguseid paradokse. Kuid võib kindel 
olla, et need teosed ei jää ilmumata: näiteks inimtekkelisele kliimasoojenemisele kui alles võrdlemisi hiljuti teadvustatud ja täienisti tehnilist päritolu globaalsele probleemile on väga lühikese aja jooksul reageerinud kliimakriisi kirjandus kui eraldi piiritletud ja kiiresti paisuv kirjandusžanr (vt Johns-Putra 2019). Muutus on tehnikaajastu üks kindlamaid konstante ning kirjandus tehnikaajastu mõtestajana muutub ühes sellega.

Läbi õhtumaise ajaloo on tehnoloogiasse ja tehnikasse suhtutud nii optimismi kui ka pessimismiga, nii vaimustuse kui ka võõritusega. Tehnika ühelt poolt võimaldab ja võimendab, teiselt poolt kammitseb ja võõrandab. Ning sageli on need toimed samaaegsed: just selles seisneb tehnika fundamentaalne ambivalentsus. Nii ei käsitle ka kirjandus tehnikat ühelgi perioodil ainuüksi positiivse või ainuüksi negatiivse jõuna. Iga Marinetti leiab omale paarikuks mõne Elioti, igale Arthur C. Clarke'ile leidub vastukaaluks oma J. G. Ballard.

Ka 20. sajandi lõpu ja 21. sajandi alguse tehnikafilosoofiast võib leida kõigutamatut tehnikausku. Üheks niisuguseks suundumuseks on transhumanism, mille pooldajate - Nick Bostromi, Hans Moraveci, Raymond Kurzweili jt - jaoks peitub tehnika intensiivistuvas arengus ja tingimusteta vastuvõtus lahendus inimkonna kõikidele hädadele. Inimkeha jõuline tehniline proteesimine, inimteadvuse digivõrgustikku laadimise perspektiiv, nanotehnoloogia ja tehisintellekti survestatud väljatöötamine jne - kõik see tõotavat inimese vabanemist tema maise keha piiratusest ning viimaks surelikkusestki. Nii päädib transhumanistlik mõtlemine õigupoolest valgustusajastul väljakujunenud keha ja vaimu, looduse ja kultuuri duaalsuse otsustava lahendamiseni vaimu ja kultuuri kasuks ning kinnistab jõuliselt inimese ülemvõimu tema keskkonna üle ühes kõikide selle negatiivsete ja katastroofiliste tagajärgedega.

Transhumanismiga võrreldes sootuks teist laadi inimese ja tehnika suhet postuleerib posthumanistlik mõttesuund, mida esindavad Cary Wolfe, N. Katherine Hayles, Donna Haraway, Bruno Latour jt. Posthumanism erineb klassikalisest humanismist selle poolest, et „taandab“ inimese „tagasi“ üheks paljudest looduslikest liikidest ning näeb inimese, tehnoloogia ja keskkonna vahel uut laadi võrdsuslikku harmooniat. Selles harmoonias pole inimesel olemuslikku õigust loodust (tehniliselt) ekspluateerida, inimõigused asetsevad samal tasandil loomaõigustega, ratsionaalse mõtlemise piiratus ja inimmõistuse ekslikkus on teadvustatult omaks võetud ning tehnika pigem soodustab kui pärsib inimese lõimimist tema keskkonda. Mõlemad mõttesuunad - nii transhumanism kui ka posthumanism - on kirjanduses ja iseäranis teadusulmes hästi esindatud. Transhumanistlikku mõttekallakut leiame läbivalt näiteks 1980. aastate küberpunkulmest. Posthumanistlikku meelestatust sobib kõige paremini ilmestama ehk Richard Brautigani luuletus „Kõik hoitud armu- 
likkuse masinate rypes“, mille ühe salmi seadsime ka käesoleva ülevaate motoks. Looduse ja tehnika uut laadi, „vastastikku programmeeruvat harmoonia[t]“ on siin esitatud nii soovunelma kui ka omamoodi eetilise imperatiivina, mille täitmisel ei peaks sobiva kollektiivse häälestuse korral olema ületamatuid takistusi. Vähemalt viimaste aastate teadusulme paistab sisendavat, et „puhta vee ja selge taeva kokkupuut“ kujundab perspektiivina üha enam kirjanduslikku kujutlusvõimet.

20. sajandi mõttelugu näitab, et tehnika areng ei vabastanud inimkonda olemise materiaalsest koormast. Vastupidi, ta sidus meid üha kindlamalt nende tehniliste protsesside ning ühendustega, mis meie maailmas-olu saadavad ja võibolla isegi määravad. Tehnoloogilisel arengul ning kultuuri üha intensiivsemal tehniseerumisel on olnud pöördumatu mõju 20. sajandi kirjandusele: nii selle temaatilistele huvija murepunktidele, vormimuutustele kui ka sellele, mida ülepea kirjanduseks on peetud. Suurt osa 20. sajandi kirjandusest võib mitmeski mõttes pidada inimese ja tehnika ülikeeruka suhte pühitsevaks või muretsevaks ülestähenduseks. Tehnika on kirjanduses olnud elu argipäevast ja ajastu meelestusest võrsunud probleem samavõrd, nagu techne oli kreeklaste jaoks argiselt elatud elu.

Sellest lähtuvalt käsitleb Methise käesolev erinumber „Kirjandus ja tehnika“ viise, kuidas kirjandus on aidanud tehnikat ja tehnoloogiat mõtestada, ning vorme, kuidas kirjandus on tehnikat representeerinud. Numbri põhituumiku moodustab valik artikleid eesti kirjandusteadlastelt, kes igaüks on kirjanduse ja tehnika teemale lähenenud oma uurimissuunast ja -huvidest lähtuvalt. Artiklid põhinevad kirjandusfestivali Prima Vista raames 11. mail 2018 TÜ raamatukogu suures saalis toimunud konverentsil „Kirjandus ja tehnika: representatsioonid ja mõtestused“ peetud ettekannetel.

Ti it Hennoste artikkel „Johannes Semper hobusega. Avangard, takerduja tehnika ja looduse vahel“ annab ülevaate 20. sajandi alguse kirjandusliku avangardi suhetest tehnikaga. Artikkel väidab, et paljud avangardi tekstiuuenduslikud ideaalid on vastuolus tehnika ideaalidega ja iseloomustavad ennekõike loodust.

Raili Marlingi artikkel „.., Muutume masinateks“. Tehnoloogia ja soolistatud kehad ameerika modernismis“ analüüsib, kuidas tehnoloogilised kuvandid sobituvad modernsuse perioodi laiemasse soolistatud kriisidiskursusesse. Marling küsib, kuidas soolistas modernism masinat ning kuidas mängisid selle soolistatud masinavärgiga modernsed naisautorid, ning kasutab kirjandusnäiteid futurismi ja dadaismiga seotud inglise-ameerika naisluuletajalt Mina Loy'lt.

Indrek Männiste artikkel „Kirjandus, kontrapunkt ja cantus technicus“ võtab muusikalisest kompositsiooniteooriast tarvitusele kontrapunkti mõiste, et 
näidata, kuidas iseäranis modernistlikes tekstides, kus tehnikat esitatakse sageli kas vastandlikuna loodusele või ängistavana tegelaste meeletundmustele, võib rääkida kontrapunktist kui poeetilisest võttest, mille eesmärk on eriomaselt rõhutada tehnika kohalolu ja kaalu tegelaste tunde- ja argielus.

Arne Merilai polemiseerib artiklis „Tehnikapööre ja luulekääne: tule jumal appi“ Martin Heideggeri tehnika mõiste, luule ja jumala suhtevahekorra üle. Heideggeri kanoonilisest mõttesängist eemaldudes ja seda kritiseerides leiab Merilai, et Heideggeri visandatud spetsiifilist laadi Jumala ilmumine ootamist ei vääri ning et moodsa tehnikaga kaasnevaid hirme ei ole tarvis ületähtsustada.

Jaak Tombergi artikkel „Küberpunk ilma teadusulmeta“ vaatleb nii poeetilisest kui ka kultuuriteoreetilisest aspektist realismi ja teadusulme otsustavat lähenemist nüüdisaegses žanrisüsteemis ning käsitleb sellest lähtuvalt küberpunkulme nüüdisaegset s(t)aatust realistliku praktikana.

Marin Laagi ja Piret Viirese artikkel „Kirjandus ja digitaalne tehnoloogia“ vaatleb, kuidas digitaalne tehnoloogia on mõjutanud kirjanduse, sh kirjandusajaloo üle mõtlemist ning kaasaegseid kirjanduslikke vorme, poeetikat, (kirjandus)loo jutustamist ja vastuvõttu. Artikkel käsitleb eesti digitaalse kirjanduse näiteid ning digihumanitaarsete meetodite võimalusi kirjanduse uurimisel.

Teooriavahenduses ilmub N. Katherine Haylesi artikkel „Intermediatsioon: ühe visiooni kannul“ I.,Intermediation: The Pursuit of a Vision“, tõlkinud Silver Rattasepp), mis pakub 20. sajandi lõpu ja 21. sajandi alguse elektroonilist kirjandust hõlmava adekvaatse teoreetilise raamistuse loomiseks välja intermediatsiooni mõiste.

Varia rubriigi sisustab Andrus La nsalu autopsühhograafiline tekst „Kirja masina ekstaatiline ümberkonstrueerimine“, kus autor avab isiklikust lugemiskogemusest lähtuvalt kirjanduse ja tehnika kokkupuutepunkte.

Vabateemalise artiklina ilmub selles numbris Roosmarii Kurvitsa „Kakskümmend viis aastat hiljem. Ajakirjanike meenutused nõukogude tsensuurist“, mille aluseks on 57 eluloolist intervjuud aastatest 2015-2016. Analüüs osutab, kuidas intervjueeritud rõhutasid enese teadlikkust nõukogude tsensuurisüsteemist ning leidsid, et kogenud ja tark ajakirjanik oskas keelde ennetavalt arvestada. Nad ei tõlgendanud seda aga mitte tsensuurile allumisena, vaid tsensuurist eemalseismisena.

\section{A l l i k a d}

Adorno, Theodor, W. ja Horkheimer, Max. 1947. Dialektik Der Aufklärung. Amsterdam: Querido Verlag. 
Arendt, Hannah. 1973. Origins of Totalitarianism. New York: Harcourt Brace Jovanovich Publishers.

Barthes, Roland 2002. Autori surm. Valik kirjandusteoreetilisi esseid. Tallinn: Varrak.

Bate, Jonathan. 2000. The Song of The Earth. Cambridge: Harvard University Press.

Baudrillard, Jean. 1999. Simulaakrumid ja simulatsioon. Tallinn: Kunst.

Blake, William. 2004a. „Korstnapühkija.” - Vikerkaar 19 (7-8): 5-6.

--_. 2004b. „London.“ - Vikerkaar 19 (7-8): 11.

Bogost, lan. 2016. „Ulysses and the Lie of Technological Progress.” - The Atlantic, 16. juuni. https://www.theatlantic.com/technology/archive/2016/06/everyday-is-bloomsday/487313/.

Borgmann, Albert. 1984. Technology and the Character of Contemporary Life. Chicago: University of Chicago Press.

Brautigan, Richard. 2007. Hanguga elavhõbedat pildudes. Tõlkinud Lauri Sommer. Tallinn: Eesti Keele Sihtasutus.

Browning, Christopher R. 2000. Nazi Policy, Jewish Workers, German Killers. Cambridge, New York: Cambridge University Press.

Cambpell, Donna M. 2017. „Naturalism in American Literature.“ - Literary Movements. https:// public.wsu.edu/ campbelld/amlit/natural.htm.

Csicsery-Ronay, Jr., Istvan. 2008. The Seven Beauties of Science Fiction. Middletown, CT: Wesleyan University Press.

Daly Nicholas. 1999. „Railway Novels: Sensation Fiction and the Modernization of the Senses.“ ELH 66 (2): 461-487. https://doi.org/10.1353/elh.1999.0013.

---. 2004. Literature, Technology, and Modernity, 1860-2000. Cambridge: Cambridge University Press.

Danius, Sara. 2002. The Senses of Modernism: Technology, Perception, and Aesthetics. Ithaca, London: Cornell University Press.

---. 2006. „Technology.“ - A Companion to Modernist Literature and Culture, toimetanud Kevin J. H. Dettmar, 66-78. Malden: Blackwell.

Debord, Guy. 2013. Vaatemänguühiskond. Tallinn: Tallinna Ülikooli Kirjastus.

Ercolino, Stefano. 2014. The Maximalist Novel. From Thomas Pynchon's Gravity's Rainbow to Roberto Bolaño's 2666. New York, London, Oxford, New Dehli, Sidney: Bloomsbury.

Ferber, Michael. 2010. Romanticism: A Very Short Introduction. Oxford: Oxford University Press.

Gillespie, Michael Patrick. 2006. „James Joyce: Ulysses.“ - A Companion to Modernist Literature and Culture, toimetanud Kevin J. H. Dettmar, 384-392. Malden: Blackwell

Gilman, Richard. 1997. „Dos Passos and the Many Lives of U.S.A.“ - The New York Times, 16. märts. https://archive.nytimes.com/www.nytimes.com/books/97/03/16/bookend/bookend.html.

Goody, Alex. 2011. Technology, Lietarture and Culture. Cambridge: Polity Press.

Hayles, N. Katherine. 2008. Electronic Literature: New Horizons for the Literary. Notre Dame: University of Notre Dame.

Heidegger, Martin. 1988. „Filosoofia lõpp ja mõtlemise ülesanne.“ - Looming 8: 1081-1088.

--_. 1989. „Küsimus tehnika järele.“ - Akadeemia 1 (2): 1195-1227. 
- - . 2004. What is Called Thinking? Tõlkinud J. Glenn Gray. New York: Perennial.

Jahn, Gary R. 1981. „The Image of The Railroad in Anna Karenina.“ - The Slavic and East European Journal 25 (2): 1-10.

Jameson, Fredric. 1997. „Postmodernism ja tarbimisühiskond“. Vikerkaar 11 (1/2): 128-141.

- - . 1999. Postmodernism, or, the Cultural Logic of Late Capitalism. London: Verso.

Johns-Putra, Adeline. 2019. Climate Change and the Contemporary Novel. Cambridge: Cambridge University Press.

Joyce, James. 2017. „Ulixes. 5. ptk: Lootosesööjad.“ Tõlkinud Kullo Vende. - Akadeemia 28 (12): 2207-2230.

Kern Stephen. 2003. The Culture of Time and Space: 1880-1918. Cambridge: Harvard University Press

Kraavi, Janek. 2005. Postmodernismi teooria ja postmodernistlik kultuur. Viljandi: Viljandi Kultuuriakadeemia.

- - - 2018. „Post-sõnastik XLII - raskusjõu vikerkaar.“ - Sirp, 1. juuni.

Landes, David S. 1969. The Unbound Prometheus: Technological change and industrial development in Western Europe from 1750 to the present. Cambridge: Cambridge University Press.

Landow, George. 2006. Hypertext 3.0. Critical Theory and New Media in an Era of Globalization. Baltimore: Johns Hopkins University Press.

Lyotard, Jean-François. 1997. The Postmodern Condition: A Report on Knowledge. Manchester: Manchester University Press.

Mann, Thomas. 2008. Võlumägi. Tõlkinud Marta Sillaots. Tallinn: Pegasus.

Miller, Tyrus. 2006. „Futurism.“ - A Companion to Modernist Literature and Culture, toimetanud Kevin J. H. Dettmar, 169-175. Malden: Blackwell.

Morton, Timothy. 2013. Hyperobjects: Philosophy and Ecology after the End of the World. Minneapolis \& London: University of Minnesota Press.

Mumford, Lewis. 1934. Technics and Civilizations. London: Routledge and Keegan Paul Ltd.

- - . 2018. Masina müüt. Tehnika ja inimareng. Tõlkinud Hillar Künnapas. Tartu: Ilmamaa.

North, Michael. 2004. Camera Works: Photography and the Twentieth Century Word. Oxford: Oxford University Press.

Nye, David E. 1994. American Technological Sublime. Cambridge: MIT Press.

Org. Andrus. 2017. Eesti ulmekirjanduse žanrid ja nende poeetika. Dissertationes litterarum et contemplationis comparativae Universitatis Tartuensis 16. Tartu: Tartu Ülikooli Kirjastus.

Orr, John. 1991. „The Modernist Novel in The Twentieth Century.“ - Encyclopedia of Literature and Critisism, toimetanud Martin Coyle, Peter Garside, Malcolm Kelsall ja John Peck, 602-618. London: Routledge.

Pound, Ezra. 1996. The Machine Art and Other Writings. Durham: Duke University Press.

Punter, David. 1991. „Romanticism.“ - Encyclopedia of Literature and Criticism, toimetanud Martin Coyle, Peter Garside, Malcolm Kelsall ja John Peck, 106-118. London: Routledge. 